\title{
O Direito e Literatura Pelas margens: o Novo BOom Latino-AmERicano E a Literatura dos SilENCIADOS
}

\author{
LAW AND LITERATURE BY THE MARGINS: THE NEW \\ LATIN AMERICAN BOOM AND THE LiteratURE OF THE \\ SILENCED
}

\section{Derecho y Literatura al margen: el Nuevo BOOM LatinoAmericano y la Literatura DE LOS SILENCIADOS}

Henriete Karam* Angela Espindola**

1 Introdução. 2 A viragem das literaturas latino-americanas. 3 Incidente em antares: o maravilhoso e a sátira política. 4 Direito e literatura: um novo boom na América Latina. 5 À guisa de conclusão. Referências.

\section{RESUMO}

Objetivo: $\mathrm{O}$ artigo tem por objetivo investigar a eventual singularidade que os estudos em Direito e Literatura apresentam no contexto da América Latina e, em especial, do Brasil.

Doutora em Estudos Literários (UFRGS). Mestre em Teoria Literária (PUCRS). Professora do Programa de Pós-Graduação em Direito da UniFG. Professora colaboradora do Programa de PósGraduação em Letras da UFRGS. Professora convidada da Escola de Humanidades-Psicanálise da UNISINOS. Membro-fundadora da Rede Brasileira Direito e Literatura (RDL). Membro do Grupo de Pesquisa Ser-Tão - Núcleo Baiano de Direito e Literatura (DGP/CNPq). São Sebastião, Guanambi - BA, BR. E-mail: <h.karam@terra.com.br>. ORCID: http://orcid.org/0000-00022166-132.

** Doutora e Mestre em Direito Público pela Unisinos. Professora Adjunta do Departamento de Direito da UFSM. Professora colaboradora do Programa de Pós-Graduação em Direito da UFSM. Professora do Programa de Pós-Graduação em Direito da UniFG. Membro-fundadora e Vice-Presidente (2019. 2020) da Rede Brasileira Direito e Literatura (RDL). E-mail: <ange.espindola@gmail.com>. ORCID: https://orcid.org/0000-0003-4376-6316. 
Metodologia: Emprega-se a perspectiva metodológica oferecida pela hermenêuticafilosófica para examinar os fatores que favoreceram o boom literário latino-americano e para compreender sua estética, através da análise dos elementos presentes no romance Incidente em Antares, de E. Verissimo.

Resultados: $O$ percurso investigativo realizado possibilitou relacionar a função que a literatura assumiu no período das ditaduras políticas que marcaram os países latinoamericanos com o papel que o movimento direito e literatura vem desempenhando no contexto social e político dos países da América Latina, pós-processos de redemocratização.

Contribuições: A possibilidade de se atribuir, aos estudos em Direito e Literatura, o estatuto de novo boom latino-americano configura-se na medida em que: (1) seu epicentro passa a ser a literatura produzida por vozes antes silenciadas, que começam a se fazer ouvir através da literatura marginal ou periférica; e (2) seus pesquisadores, que superam o senso comum acrítico, assumem um compromisso jurídico, social e político com aqueles que se encontram ou são colocados à margem.

Palavras-chave: Direito e literatura. Boom latino-americano. Realismo fantástico. Literatura marginal.

\section{ABSTRACT}

Objective: The article aims to investigate the possible singularity that studies in Law and Literature present in the context of Latin America and, in particular, Brazil.

Methodology: The methodological perspective offered by the hermeneuticsphilosophical is used to examine the factors that favored the Latin American literary boom and to understand its aesthetics, through the analysis of the elements present in the novel Incidente em Antares, by E. Verissimo.

Results: The investigative path carried out made it possible to relate the role that literature assumed during the period of political dictatorships that marked Latin American countries with the role that the law and literature movement has been playing in the social and political context of Latin American countries, post-process of redemocratization.

Contributions: The possibility of attributing, to studies in Law and Literature, the status of a new Latin American boom is configured insofar as: (1) its epicenter becomes the literature produced by voices previously silenced, which begin to become making heard through marginal or peripheral literature; and (2) its researchers, who surpass uncritical 
common sense, assume a legal, social and political commitment with those who are or are left out.

Keywords: Law and literature. Latin American boom. Fantastic realism. Marginal literature.

\section{RESUMEN}

Objetivo: El artículo tiene como objetivo investigar la posible singularidad que los estudios de Derecho y Literatura presentan en el contexto de América Latina y, en particular, de Brasil.

Metodología: Se utiliza de la perspectiva metodológica que ofrece la hermenéuticafilosófica para examinar los factores que favorecieron el boom literario latinoamericano y para comprender su estética, a través del análisis de los elementos presentes en la novela Incidente em Antares, de E. Verissimo.

Resultados: La trayectoria investigativa realizada permitió relacionar el rol que asumió la literatura durante el período de dictaduras políticas que marcaron a los países latinoamericanos con el rol que viene jugando el movimiento de derecho y literatura en el contexto social y político de los países latinoamericanos, postproceso de redemocratización.

Contribuciones: La posibilidad de atribuir, a los estudios de Derecho y Literatura, el estatus de un nuevo boom latinoamericano se configura en la medida en que: (1) su epicentro se convierte en la literatura producida por voces previamente silenciadas, que comienzan a convertirse en haciéndose oír a través de la literatura marginal o periférica, y (2) sus investigadores, que superan el sentido común acrítico, asumen un compromiso jurídico, social y político con los excluídos y los marginales.

Palabras clave: Derecho y literatura. Boom latinoamericano. Realismo fantástico.L marginal.

\section{INTRODUÇÃO}

A construção identitária, a expressão de sua subjetividade e o reconhecimento, por parte do outro, da singularidade são fatores estruturantes do discurso contrahegemônico, que, no contexto latino-americano, constituem os potenciais emancipatórios de uma sociedade e de seu direito, tendo a produção literária dos países da América Latina promovido, de modo muito particular, avanços emancipatórios bastante relevantes, a partir da segunda metade do séc. XX. 
Desde Artur Uslar Pietri (Venezuela), considerado o pai do realismo mágico, passando por Miguel Angel Astúrias (Guatemala), Alejo Carpentier (Cuba), Jorge Luis Borges e Julio Cortázar (Argentina), Murilo Rubião e José J. Veiga (Brasil), Gabriel García Márquez (Colômbia), Carlos Fuentes (México), Mario Vargas Llosa e Isabel Allende (Peru), entre outros tantos, é possível identificar muito facilmente a formação de um discurso contra-hegemônico na literatura latino-americana, discurso este que se instaurou com o realismo mágico dos anos 60-70.

A comunidade de escritoras e escritores latino-americanos representa o espaçotempo da resposta latino-americana à literatura europeia, uma expressividade decolonial, uma fonte de descolonização do imaginário latino-americano. Essa comunidade de escritoras e escritores questiona e fragiliza saberes colonizados de modo bastante ímpar, provocando contornos muito particulares nos estudos e pesquisas de Direito e Literatura na América Latina e, muito especialmente, no Brasil.

A dualidade entre os discursos hegemônico e contra-hegemônico, bem como - e sobretudo - o embate entre a literatura sancionada, que reforça o estado das coisas, e a literatura proscrita, que produz a negação do estado de coisas dominante (CANDIDO, 2004), impulsionam os estudos e pesquisas do Direito e Literatura na América Latina à condição de novo boom latino-americano. Eis aqui a pretensão deste artigo: caracterizar o movimento Direito e Literatura como um novo boom latino-americano.

Para a construção do argumento dessa tese, o artigo divide-se em três partes. A primeira aborda a importância do boom latino-americano na ruptura com os padrões literários eurocêntricos e na fundação de uma estética cujos procedimentos e repertório temático possibilitaram representar e expressar as idiossincrasias dos países da América Latina. A segunda parte é dedicada ao romance Incidente em Antares, de Érico Veríssimo ${ }^{1}$, sendo destacado o conjunto de elementos em que se sustenta a articulação entre o maravilhoso, o sentido alegórico e a sátira política. Já na terceira e última parte, valendo-se de metáforas de Incidente em Antares, de Érico Veríssimo e da reconstrução do realismo fantástico latino-americano, pretende-se demonstrar as origens de um discurso contra-hegemônico radicadas no surgimento de uma literatura proscrita na América Latina. Essa literatura pouco a pouco assume novos contornos, corpos insepultos são tornados visíveis e, mais tarde, vozes silenciadas tomam de assalto a palavra.

No diversificado contexto da América Latina, o Direito e Literatura se manifesta plural em suas singularidades, podendo ser reconhecido hoje, conforme se defende aqui, como um novo boom latino-americano. Certamente, esse argumento preliminar, deverá desencadear em pesquisa futura, com vistas a destacar os impactos desse fenômeno para

\footnotetext{
1 A metodologia empregada na análise dos elementos diegéticos e discursivos é aquela postulada por Karam (2017), com base nos estudos narratológicos.
} 
o modo de produção do Direito. Importante, portanto, que esse artigo gere outros diálogos e outras pesquisas.

\section{A VIRAGEM DAS LITERATURAS LATINO-AMERICANAS}

O fenômeno literário e editorial denominado boom latino-americano continua gerando, nos campos da historiografia e da crítica literárias, amplo espectro de discussões seja na definição de seus marcos e escritores representativos, seja no levantamento dos fatores que contribuíram para a difusão das obras e, consequentemente, a internacionalização das literaturas latino-americanas, seja, ainda, nas relações entre os cenários político e literário das décadas de 60-70 do século XX.

Impõe-se, assim, explicitar que o interesse, aqui, restringe-se a tecer algumas considerações sobre os elementos linguísticos, estéticos e temáticos que configuraram o realismo mágico ${ }^{2}$ e possibilitaram que as produções literárias dos países latinoamericanos apresentassem feições próprias e tivessem suas singularidades reconhecidas.

Nesse contexto, adquire relevância o processo de ruptura com os padrões eurocêntricos - processo que inicia não com a exaltação nacionalista e a idealização do estado de natureza preconizados pela estética do romantismo, mas com o realismo social da década de 30, que tem como marca essencial a denúncia de injustiças sociais e que antecipando técnicas narrativas do realismo mágico - incorpora, à narrativa literária, a realidade de seu povo, suas tradições, seus costumes, sua linguagem...

De fato, é preciso considerar dois aspectos: de um lado, que o texto literário se distingue dos demais gêneros textuais por sua capacidade intrínseca de transgressão, de subversão, da língua e das próprias convenções estéticas já estabelecidas; de outro, que as literaturas dos países latino-americanos necessitaram realizar uma longa trajetória de individuação para se desvincularem da linguagem do outro, do europeu.

Em suma, o que se busca destacar é que a imposição linguística e cultural decorrente do processo de colonização foi determinante para que, durante quatrocentos

\footnotetext{
A expressão realismo mágico começa a ser empregada, no final dos anos 40, para designar a nova modalidade de ficção literária que surgia na América Latina e que se caracterizava pela oposição tanto à estética realista e naturalista do séc. XIX quanto ao regionalismo modernista. Segundo Martin (2002), os precursores do realismo mágico são Jorge Luis Borges (Argentina), Alejo Carpentier (Cuba), Miguel Ángel Asturias (Guatemala), Arturo Uslar Pietri (Venezuela), Juan Rulfo (México), Juan Carlos Onetti (Uruguai) e Mário de Andrade (Brasil). A geração seguinte conjuga nomes como Adolfo Bioy Casares (Argentina), José Lezama Lima (Cuba), José María Arguedas (Peru), Roa Bastos (Paraguai), Guimarães Rosa e Clarice Lispector (Brasil). Já o boom latino-americano congrega, restritivamente, os escritores Julio Cortázar (Argentina), Mario Vargas Llosa (Peru), Gabriel García Márquez (Colômbia) e Carlos Fuentes (México).
} 
anos, as literaturas latino-americanas se vissem compelidas a adotar padrões e modelos exógenos.

Considerando tal contexto, é possível perceber que a produção literária da América Latina dos anos 60-70 caracteriza-se pela confluência de três fatores, dos quais decorre sua importância: (1) o fortalecimento do processo de conscientização identitária, desencadeado no campo literário pelo realismo social; (2) a consolidação de uma estética das idiossincrasias latino-americanas; e (3) o reconhecimento e legitimação das literaturas latino-americanas no âmbito internacional.

Esses três fatores correspondem aos componentes que, no plano individual, possibilitam a inscrição de um sujeito na cultura: a construção identitária, a expressão da subjetividade e o reconhecimento, por parte do outro, de sua singularidade ${ }^{3}$.

Concorre, entretanto, no caso das produções literárias, um quarto elemento que poderia inviabilizar a articulação de tais fatores: a restrição à liberdade de expressão no cenário das ditaduras políticas que, nesse período histórico, assolaram os países da América Latina. $\mathrm{O}$ efeito desse quarto elemento é decisivo pois, ao que tudo indica, a restrição à liberdade de expressão teria atuado como mola propulsora da criatividade, na qual o fantástico e o maravilhoso vêm desempenhar relevante papel.

Assim, paralelamente ao compromisso de denúncia tanto da miséria, injustiça e marginalização social, quanto da repressão política vigente, há o resgate das construções imaginárias e simbólicas de mitos e lendas das tradições orais, seja das comunidades autóctones dos países latino-americanos, seja das diferentes etnias que foram compondo suas nações. Foi esse resgate de elementos de imaginários coletivos muitas vezes reprimido ou segregado que forneceu figuras e expressões singulares e estilos originais e autênticos.

Dá-se, assim, o surgimento do realismo mágico ${ }^{4}$ - ou do real maravilhoso, como propõem Carpentier (1966) -, que conjuga o sobrenatural do vasto universo mágico oriundo das narrativas orais com a dura realidade imposta pela dominação, pela tirania e pela corrupção. Resulta dessa fusão uma narrativa que, com novo repertório temático e novos procedimentos estéticos, tem como principais marcas, de um lado, a diversidade, evidenciada pela presença de personagens de diferentes estratos sociais, pelo emprego de distintos gêneros textuais, pela adoção de múltiplas vozes e pontos de vista narrativos, e,

3 Tal inscrição na cultura exige que o sujeito adote o sistema de signos que o precede (langue) e que, ao empregá-lo (parole), seja capaz de, em alguma medida, transgredi-lo para expressar sua subjetividade na relação intersubjetiva (KARAM, 2017, p. 1029).

4 Segundo Luis Leal, em El realismo mágico en la literatura hispanoamericana, o termo foi cunhado por Roh (2013), historiador de arte alemão, em 1925, para referir o realismo pós-expressionista. Posteriormente, foi adotado por Pietri (1995), na obra Letras y hombres de Venezuela, publicada em 1948. 
de outro lado, o hibridismo, com a mescla de história e ficção ${ }^{5}$, de realidade e sobrenatural, e com a constante recorrência à intertextualidade e à paródia.

Essas são as características a serem abordadas na leitura, a ser oferecida aqui, do romance Incidente em Antares, de Erico Verissimo ${ }^{6}$, a fim de destacar que, sendo o maravilhoso determinante para o sentido alegórico da obra e, consequentemente, para configurar seu caráter de sátira política, é também o maravilhoso que possibilita elidir a censura e exercer a liberdade de expressão, apesar dos cerceamentos a ela impostos pela ditadura militar?

\section{INCIDENTE EM ANTARES: O MARAVILHOSO E A SÁTIRA POLÍTICA}

Incidente em Antares é o último romance de Erico Veríssimo e foi publicado em 1971, durante o governo do General Emílio Garrastazu Médici, o mais repressivo e violento do regime militar brasileiro.

Esse momento histórico se caracteriza pela incrementação dos órgãos de repressão (SNI, DOPS, DOI-CODI $)^{8}$, pela censura da imprensa e das produções culturais, pelas prisões arbitrárias e suspensão da garantia de habeas corpus, pelo combate aos movimentos populares de esquerda e aos movimentos estudantis e sindicais, pela prática da tortura e assassinato dos opositores ao regime.

Paralelamente, havia a maciça difusão da propaganda do regime - é dessa época o slogan Brasil: ame-o ou deixe-o e as músicas Este é um país que vai pra frente e Eu te amo, meu Brasil -, bem como a exaltação do milagre econômico brasileiro e da conquista do tricampeonato brasileiro na Copa do Mundo da FIFA de 1970.

Tudo isso com o objetivo de disseminar o otimismo e de eludir a violação dos direitos políticos e a supressão de direitos e garantias individuais.

5 Para a profundar as relações entre história e ficção, sobretudo no que diz respeito à metaficção historiográfica, sugere-se a leitura do artigo "História, direito e literatura" (KARAM; ALCÂNTARA, 2019).

6 Embora Erico Verissimo não faça parte do grupo de escritores vinculados ao boom latino-americano e tampouco possa ser considerado um expoente do realismo mágico brasileiro - como é o caso de Rubião (2010), que produz suas narrativas nos anos 30 e 40, bem como de José J. Viega (1976), com seu célebre romance A hora dos ruminantes, lançado em 1966 -, Incidente em Antares faz parte, por suas características narrativas, das obras que se incluem no quadro do realismo mágico

7 No mesmo sentido, Maia (2016, p. 377) afirma que "O realismo surge como uma forma de reação, utilizando o elemento mágico como reforço das palavras contrárias aos regimes dos ditadores, tentando driblar a censura comum a esses regimes."

8 Serviço Nacional de Informação (SIN), Departamento de Ordem Política e Social (DOPS) e Destacamento de Operações e Informações - Centro de Operações e Defesa Interna (DOI-CODI). 
O romance Incidente em Antares é dividido em duas partes, e em ambas a narrativa se constitui pela articulação que o narrador extradiegético ${ }^{9}$ e onisciente estabelece entre seu próprio discurso e os discursos que, produzidos por diferentes enunciadores, ele transcreve. A essa dimensão polifônica da narrativa vem se somar a inserção, no relato, de distintos gêneros textuais: crônica de viagem, carta, diário íntimo, reportagem jornalística, anotações de pesquisa de campo, livro científico...

Quanto ao enredo, a primeira parte do romance - intitulada Antares - inicia com a alusão a achados fósseis do período pré-histórico e ao surgimento dos primeiros espécies de homo sapiens na zona do Brasil meridional. Depois, relata a fundação da fictícia cidade de Antares: no início do séc. XIX, surge um pequeno vilarejo denominado Povinho da caveira - que se situa, geograficamente, na região missioneira, à margem do rio Uruguai, fronteira entre o Brasil e a Argentina -, nas terras de Francisco Vacariano, estancieiro e senhor absoluto que governava a pequena comunidade ribeirinha; em 1853, o vilarejo é elevado à vila e recebe o nome de Antares; poucos anos depois, em 1860, um criador de gado, Anacleto Campolargo, compra terras e se estabelece na região. A seguir, são narradas a acirrada rivalidade e as violentas disputas de poder entre os dois clãs e, na sequência, os conchavos das duas famílias tradicionais de Antares, dignos representantes da oligarquia rural, que se tornam aliadas em prol da manutenção de seus privilégios.

A vida em Antares segue o curso da história brasileira, sendo frequentes as referências dos narradores e das personagens a fatos e vultos do mundo empírico. Desse modo, Antares constitui um microcosmo que possibilita analisar, sob a perspectiva de uma cidade do interior do sul do Brasil, os problemas sociais, políticos e econômicos do país, desde as primeiras décadas do século XIX até os anos 60 do séc. XX.

$\mathrm{Na}$ primeira parte do romance, temos a representação da sociedade brasileira ao longo de mais de um século e nela se entrecruzam eventos e personagens ficcionais e históricos. Dessa combinação de história e ficção decorre os efeitos de real (BARTHES, 1971), que imprimem verossimilhança e autenticidade ao relato. Assegurada a credibilidade, na segunda parte - intitulada $\mathrm{O}$ incidente -, real e sobrenatural se mesclam: durante uma greve geral, sete mortos cujos corpos ficaram insepultos voltam à "vida".

Tal insólito incidente - que, ironicamente ocorre no dia 13 de dezembro de 1963, uma sexta-feira - adquire proporções catastróficas na medida em que os mortos se dirigem à praça central da cidade para reivindicar o direito de serem enterrados.

9 O termo extradiegético é empregado por G. Genette ([s.d.]) em sua taxonomia do narrador. Trata-se do narrador que não participa dos eventos, ou seja, que não é personagem da história e que, produzindo uma narrativa primeira, dirige-se ao narratário extradiegético, que corresponde ao leitor virtual. 
A descrição do cortejo dos defuntos rumo à praça é oferecida no relato de um dos narradores-personagem. Diz ele:

sete mortos, em sinistra formatura, desceram sobre a cidade, [...] semeando o
susto, o pavor e o pânico. Pareciam [...] figuras egressas dum grotesco museu
de cera [...] os defuntos se moviam de maneira rígida, como bonecos de mola a
que alguém - Deus ou o diabo? - tivesse dado corda. E seus olhos, fitos num
ponto indefinível do horizonte, estavam cobertos duma espécie de película
que para uns parecia viscosa e brilhante e para outros fosca. Causou
estranheza o fato de seus corpos não produzirem nenhuma sombra. Não
foram poucos os cidadãos antarenses que recusaram dar crédito ao que viam,
julgando-se vítimas duma alucinação. Mortos ressurrectos? Fantasmas? Era
incrível! Pavoroso! (VERISSIMO, 2006, p. 267).

Os sete mortos revividos vêm reforçar o caráter polifônico do romance. No plano discursivo, a polifonia resulta do emprego de múltiplos narradores, como já destacado; no plano diegético, decorre do fato de que entre os defuntos há representantes de diferentes classes sociais, ideologias e concepções de mundo. Os mortos são:

- Dona Quitéria, matriarca dos Campolargos e presidente da sociedade Legionários da Cruz, associação que atua em defesa da Família, da Tradição e da Propriedade;

- o Dr. Cícero Branco, advogado, articulador e testa de ferro das falcatruas entre os poderosos da cidade;

- Barcelona, sapateiro e líder anarcossindicalista;

- João Paz, jovem operário, engajado na luta sindical, que havia sido injustamente preso, torturado e morto pela polícia;

- Menandro Olinda, pianista promissor que, após uma crise nervosa em seu primeiro concerto, nunca mais fez apresentações públicas e tornara-se alvo da zombaria dos habitantes de Antares;

- Erotides, prostituta que quando jovem tivera como clientes homens da alta sociedade local e que morrera tísica e na miséria; e

- Pudim de Cachaça, um dos bêbados da cidade, que fora envenenado por sua mulher, em quem batia com frequência.

$\mathrm{Na}$ praça pública - que assume a dimensão da ágora democrática grega -, há o confronto dos defuntos, que exigem ser sepultados imediatamente, com as autoridades locais: o prefeito, Major Vivaldino Brazão, o Coronel Tibério Vaquariano, o delegado Inocêncio Pigarço, o juiz e o promotor público.

Destaque-se, aqui, a carga semântica dos nomes próprios e o efeito irônico que eles produzem: o prefeito é Vivaldino; o caudilho coronel que representa as oligarquias rurais tem o nome de um imperador romano, o delegado de polícia, "homem cruel, um torturador de prisioneiros políticos", chama-se Inocêncio... 
Com a declaração do prefeito de que o sepultamento só será possível após o término da greve geral e seu pedido de que voltem ao seus caixões e aguardem, os sete mortos - livres das pressões sociais e sem razão para temerem qualquer tipo de represália - passam a denunciar publicamente tanto as hipocrisias e o falso moralismo de seus concidadãos quanto a corrupção de seus governantes, a prática da tortura, os atos de violência, os abusos e as arbitrariedades impetradas pelos detentores do poder e seus mandatários.

A praça se transforma em tribunal: o Dr. Cícero, apresentando-se como advogado dos demais, acusa o Coronel Tibério e o prefeito Vivaldino de peculato, de enriquecimento ilícito à custa dos cofres públicos; e o anarcossindicalista Barcelona, revela casos de adultério, de contrabando, de venda ilegal de medicamentos controlados e de exploração sexual.

As autoridades procuram inverter a situação: o juiz e o promotor de justiça são instados pelo prefeito a se manifestarem e a tratarem os sete defuntos como se fossem réus. Eles são acusados pelo promotor de conspurcar a dignidade da morte; o Coronel Vaquariano exige que o juiz considere seus testemunhos inválidos, pois os mortos não têm autoridade para falar; o juiz alerta que o advogado está se autoincriminando ao confessar ter participado de negociatas, mas o Dr. Cícero contra-argumenta que a morte thes confere imunidade e que eles se encontram fora do alcance da lei.

A multidão que vai se reunindo na praça e que assiste à cena se divide entre os que se mantêm atrás das autoridades, durante a maior parte do tempo em silêncio soturno e amedrontado, e os jovens que haviam subido nas árvores e sentados em seus galhos aplaudiam, vaiavam, gritavam impropérios e palavras de ordem, sendo nomeados por um dos personagens de macacos comunistas, que vem se somar à convicção do delegado de que os jovens são teleguiados de Moscou e às conclusões do coronel Tibério de que, no insólito evento, há certamente o dedo comunista e que até no céu já existe infiltração comunista.

O contraponto à carga ideológica que subjaz a tais afirmações aparece no discurso de um dos narradores-personagem: "Comunista é o pseudônimo que os conservadores, os conformistas e os saudosistas do fascismo inventaram para designar simplisticamente todo o sujeito que clama e luta por justiça social.” (VERISSIMO, 2006, p. 390).

Esse paradigmático confronto de ideologias ilustra apenas um dos procedimentos que asseguram o caráter dialógico do romance. O principal deles é a intertextualidade, sendo recorrentes as alusões diretas e indiretas a obras e autores da literatura ocidental. Três dessas alusões merecem ser destacadas aqui.

O repórter designado pelo jornal da capital para averiguar o incidente viera acompanhado de um fotógrafo, "seu fiel escudeiro", segundo o narrador, que acrescenta: "Como a vida nem sempre imita a arte, o jornalista de barba quixotesca era 
de estatura mediana e fornido de carnes. Seu Sancho Pança era alto e magro como o Quixote de Cervantes." (VERISSIMO, 2006, p. 459).

Há em Antares o Kafé Kafka, descrito como

uma espécie de clube exclusivo que tinha apenas doze sócios (estudantes ricos e esnobes) e cuja sede - um porão que imitava uma cave existencialista parisiense - só se abria durante as férias de verão. (Afirmavam seus sócios que em matéria de literatura, fora de Kafka, Joyce e Proust não havia salvação.) (VERISSIMO, 2006, p. 459).

Um dos narradores relata que, ao sentir o gosto de um bolinho experimentara o milagre proustiano da madaleine, e transcreve, em francês, uma emblemática frase do episódio de À la recherche $d u$ temp perdu. Ato contínuo, se justifica: "que importa seja uma paródia?" (VERISSIMO, 2006, p. 186).

De fato, a paródia, com seu tom carnavalizante, e o maravilhoso são as molas mestras da sátira política que a narrativa oferece e do sentido alegórico que lhe pode ser atribuído, face à realidade brasileira da época em que o romance é produzido e vem a público.

Mas além da intertextualidade, tem-se também a intratextualidade. Um dos personagens-narrador é descendente da família Terra Cambará, que ocupa posição central na trama de outro romance de Erico Veríssimo, O tempo e o vento. Veríssimo, aliás, não só é nomeado em Incidente em Antares, como há um breve relato de sua visita à cidade:

D. Quita fala então "nas indecências de nossa época". Está escandalizada e alarmada ante [...] a expansão da pornografia em revistas, livros, filmes, peças de teatro...

- Sei que a senhora gosta de ler - digo.

- Muito. [...] Devorei todo o Walter Scott e o Alexandre Dumas. Nunca suportei o Zola nem o Flaubert. Mas gostava do Tolstoi. Ah! leio também os modernos. Estrangeiros e nacionais, naturalmente.

- Já leu Jorge Amado?

- Por alto. É bandalho e comunista.

- E o nosso Erico Veríssimo?

- Nosso? Pode ser seu, meu não é. Li um romance dele que fala a respeito do Rio Grande de antigamente. [...] Há uns anos o Veríssimo andou por aqui, a convite dos estudantes, e fez uma conferência no teatro. [...] Não gostei, mas podia ter sido pior. Quem vê a cara séria desse homem não é capaz de imaginar as sujeiras e despautérios que ele bota nos livros dele (VERISSIMO, 2006, p. 412).

Concluída a digressão, cabe retomar o enredo do romance. 
João Paz é o último dos mortos insepultos a ser chamado pelo Dr. Cícero para depor: a testemunha mais importante, declara o advogado. No romance, João Paz vem representar todos aqueles que são perseguidos, torturados e mortos pelo regime militar.

Tal representação é reforçada na medida em que, estrategicamente, não há o depoimento de João Paz na narrativa. Seu testemunho são as marcas no seu corpo, visíveis a todos, que podem, então, testemunhá-las. O Dr. Cícero se encarrega de descrever, em detalhes, as técnicas que foram empregadas e apontar, no corpo de João $\mathrm{Paz}$, os resultados produzidos, solicitando aos presentes - e obviamente ao leitor - que usem sua imaginação. Diz o Dr. Cícero Branco:

Acho que todos poderão ver estas manchas arredondadas na cara e nas mãos de João Paz... Pois foram produzidas por pontas de cigarros acesos, na primeira fase do interrogatório... coisa leve, digamos... uma espécie de batebola inicial... [...]

Os carrascos passaram então à segunda fase do interrogatório. Dois brutamontes puseram-se a bater em Joãozinho, aplicando-lhe socos e pontapés no rosto, na boca do estômago e nos testículos... [...]

O prisioneiro depois de toda essa violência recusa ainda falar. Já desmaiou de dor duas vezes e foi revivido com água gelada. $\mathrm{Na}$ fase seguinte aplicam-lhe pauladas no corpo todo e o resultado é um braço quebrado em três lugares. Vejam... [...]

Vem então a fase requintada. Enfiam-lhe um fio de cobre na uretra e outro no ânus e aplicam-lhe choques elétricos. O prisioneiro desmaia de dor. Metemlhe a cabeça num balde d'água gelada e, uma hora depois, quando ele está de novo em condições de entender o que the dizem e de falar, os choques elétricos são repetidos... [...]

O especialista nestas torturas elétricas cometeu um erro, aplicou no prisioneiro uma descarga forte demais e o coração do moço parou. O médico é chamado às pressas. [...] $\mathrm{O}$ nosso bondoso, o nosso caritativo, o nosso altruístico Dr. Lázaro Bertiogal [...]

Nosso bom doutor tenta tudo. Respiração artificial. Injeção de adrenalina e massagens no coração da vítima. Inútil! João Paz está morto. [O delegado] Inocêncio Pigarço fica assustado. A solução para evitar um escândalo é enterrar secretamente o cadáver no pátio da delegacia (Não seria o primeiro!) e depois espalhar a mentira de que João Paz fugiu para a Argentina...[...] [Outr]a encenação é feita. Vem até a delegacia uma ambulância do [Hospital] Salvator Mundi, o prisioneiro é devidamente vestido como estava quando entrou na prisão. [...] Menos de duas horas depois o cadáver está dentro dum caixão fechado e o nosso Hipócrates assina um atestado de óbito dando como causa mortis uma embolia pulmonar (VERISSIMO, 2006, p. 478-479).

A transcrição do discurso do Dr. Cícero é acompanhada pelo relato ora das manifestações de indignação e de ódio dos jovens arborícolas ora dos urubus que sobrevoam a praça em círculos cada vez mais baixos. 
Feitas as denúncias, os mortos se calam e sentam imóveis no coreto da praça. A comitiva das autoridades bate em retirada "como um exército derrotado", nas palavras do narrador. A população se dispersa.

Poucas horas depois, nova onda de pânico: estimulados pelo odor putrefato que exala dos corpos dos mortos, ratos surgem de todos os cantos da cidade e se dirigem para a praça central.

Segundo o narrador, um professor público "que vivia obcecado pelo perigo amarelo [...] comparou esses daninhos animais com guerrilheiros da Indochina que pareciam ter lido com proveito os manuais chineses e cubanos sobre a técnica da guerrilha urbana." (VERISSIMO, 2006, p. 383).

O terror absoluto toma conta dos habitantes de Antares quando "Os urubus entram numa luta encarniçada com os ratos, atacando-os a bicadas, e diante dessa sangrenta disputa os sete mortos parecem manter-se impassíveis, na mais rigorosa neutralidade." (VERISSIMO, 2006, p. 383).

No dia seguinte, os mortos retornam a seus caixões e são sepultados. O narrador, em clara alusão às demais ditaduras da América Latina, em tom irônico declara: "Deus é bom. Cedo, na manhã daquele sábado [...] um vento forte começou a soprar em Antares, de leste para oeste, varrendo na direção da Argentina e de outras repúblicas vizinhas, os miasmas e o mau cheiro deixado pelos mortos na Praça da República e arredores." (VERISSIMO, 2006, p. 453).

À tarde chegam repórteres e fotógrafos dos jornais da capital para fazer a cobertura do insólito incidente, mas os planos dos poderosos de Antares já estão traçados: as autoridades declaram que a notícia dos "mortos ressuscitados" não passara de uma jogada de marketing cuja finalidade era chamar a atenção do país para a cidade de Antares e divulgar uma feira agropastoril que aconteceria no ano seguinte.

Com o passar do tempo, a vida volta à sua rotina normal em Antares. As denúncias feitas pelos mortos são esquecidas graças à denominada operação borracha, estratégica campanha promovida pelas autoridades com o intuito de eliminar o insólito episódio da história de Antares e da memória de seus habitantes.

Sete anos depois - e nesse momento da narrativa o tempo da diegese coincide com o tempo da enunciação -, o macabro incidente estava completamente esquecido.

O narrador conclui o relato do seguinte modo:

Antares é hoje em dia uma comunidade próspera e feliz.

Como, porém, nada é perfeito neste mundo, às vezes na calada da noite vultos furtivos andam escrevendo nos seus muros e paredes palavras e frases politicamente subversivas, quando não apenas pornográficas.

Os dedicados guardas municipais, sempre alerta, dão-lhes caça dia e noite. Numa destas últimas madrugadas abriram fogo contra um estudante que, com broxa e piche, tinha começado a pintar um palavrão num muro da Rua 
Voluntários da Pátria. Na calçada, no lugar em que o rapaz caiu, ficou uma larga mancha de sangue enegrecido, na qual a imaginação popular - talvez sugestionada por elementos da esquerda - julgou ver a configuração do Brasil. (É assim que nascem os mitos.)

Cedo, na manhã seguinte, empregados da prefeitura vieram limpar a calçada dessa feia mácula, e quando começaram a raspar do muro o palavrão, aos poucos se foi formando diante deles um grupo de curiosos.

Aconteceu passar por ali nessa hora um modesto funcionário público que levava para a escola, pela mão, o seu filho de sete anos. O menino parou, olhou para o muro e perguntou:

- Que é que está escrito ali, pai?

- Nada. Vamos andando, que já estamos atrasados...

O pequeno, entretanto, para mostrar aos circunstantes que já sabia ler, olhou para a palavra de piche e começou a soletrá-la em voz muito alta:

- "Liber...".

- Cala a boca, bobalhão! - exclamou o pai, quase em pânico. E, puxando com força a mão do filho, levou-o, quase de arrasto, rua abaixo (VERISSIMO, 2006, p. 489).

Essa imagem final, na qual um pai tenta, desesperadamente, impedir seu filho de ler a palavra liberdade, denuncia o estado de terror promovido pelos regimes ditatoriais e, ao mesmo tempo, revela que a resistência à opressão e à censura tem como aliada a impossibilidade de erradicar as aspirações que, como a liberdade de expressão, são intrínsecas ao ser humano.

\section{DIREITO E LITERATURA: UM NOVO BOOMNA AMÉRICA LATINA}

Quando E. Marí escreveu, em 1998, o seminal artigo Derecho y literatura, incluindo-lhe o subtítulo algo de lo que sí se puede hablar pero en voz baja, talvez não imaginasse que, vinte anos depois, os estudos dedicados à articulação do direito com a literatura fossem adquirir a audibilidade e visibilidade que hoje têm, em diferentes países da América Latina.

Não faltam exemplos de pesquisadores e de centros de investigação - na Argentina, no Uruguai, no Peru, na Colômbia, em Porto Rico, no México, no Equador, no Brasil -, sua produção, além de expressiva e relevante, adquire feições próprias, tão singulares quanto o contexto em que se inserem.

Essa singularidade possibilita a analogia com o boom literário dos anos 60-70, pois, na América Latina, o movimento Direito e Literatura surge para questionar as relações entre linguagem e poder, bem como os mecanismos de exclusão social que inviabilizam o exercício da cidadania e a participação política, vem incorporar as narrativas plurais que compõem o tecido social, atentar para as violações aos direitos e garantias fundamentais e reivindicar sua tutela e proteção. 
Sinteticamente, pode-se dizer - parafraseando o sugestivo título do livro que reúne textos dos alunos de pós-graduação em direito da Universidad Nacional Autónoma de México - que Direito e Literatura é una alianza que subvierte el orden (CERVANTES, 2017).

O principal efeito dessa subversão da ordem parece ser, justamente, o potencial dos estudos em Direito e Literatura para refletir sobre os impasses e os desafios a serem enfrentados pelas jovens democracias da América Latina, de modo a concretizar os direitos e garantias que estão assegurados nas suas recentes cartas constitucionais - em sua maioria promulgadas nas décadas de 80 e 90 -, cumprindo as promessas do estado social e democrático de direito que possibilitam a consolidação de sociedades plurais mais justas e igualitárias.

É essa juventude democrática que potencializa os estudos e pesquisas em Direito e Literatura na América Latina. Certamente, o direito e a literatura são campos distintos e operam distintamente: enquanto o direito codifica a realidade, a literatura libera os possíveis; enquanto o direito desempenha uma função social que lhe impõe estabilizar expectativas e tranquilizar angústias, a literatura possui uma função heurística e é livre para entregar-se às variações imaginativas e para criar surpresas; enquanto o direito produz pessoas, a literatura produz personagens; enquanto o direito curva-se ao geral e prospecta o abstrato, a literatura se desdobra no particular e no concreto (OST, 2004, p. 15).

O direito e a literatura possuem estatutos discursivos distintos. No entanto, distinguir a literatura do direito, e vice-versa, está longe de conduzir à conclusão de que a literatura é alheia às normas e às formas instituídas ou de que o direito atua apenas nas posições instituídas, sem exercer função instituinte.

O direito supõe, em alguma medida, tal qual a literatura, a criação imaginária de significações sociais-históricas novas e a desconstrução das significações instituídas que a elas se opõem (OST, 2004, p. 19). O direito, tal qual a literatura, movimenta-se a partir de choques e forças centrífugas oriundas de situações particulares e dramas individuais. As narrativas literárias, por sua vez, constituem-se como fonte do imaginário jurídico; e o bom latino-americano carrega essa potência.

Assim, partindo da compreensão de que o boom (literário) latino-americano experimentado nos anos 60-70 redimensionou o imaginário (jurídico) latino-americano, vamos identificá-lo como elemento prévio e importante para a redemocratização dos países a partir dos anos 80 , com influência no constitucionalismo latino-americano. É inegável que, se o boom latino-americano dos anos 60-70, contrapôs discursos e fomentou reflexões sobre a estrutura social dos países, ele também potencializou uma contínua literatura proscrita diante de uma literatura sancionada. Esse confronto - entre a literatura sancionada e a proscrita - criou o espaço e a dramatização necessários para 
se compreender a complexidade de determinado momento histórico e de determinada cultura.

No entanto, com o distanciamento temporal, é possível constatar que as obras precursoras e as obras vinculadas ao boom latino-americano não são autenticamente polifônicas ${ }^{10}$, em que pese a sua relevância e a contribuição para aquele momento latinoamericano, fortemente marcado por ditaduras, pela censura e pela cassação de direitos. O boom latino-americano constituiu-se a partir de uma literatura proscrita (CANDIDO, 2004), mas que ainda era produzida por uma elite intelectual, por escritoras e escritores privilegiados, vindos de lugares privilegiados e ocupando posições privilegiadas ${ }^{11}$.

Por certo que isso não reduz a importância do boom latino-americano, mas é um dado que merece ser considerado não só na história da literatura e da cultura latinoamericana, como, especialmente, no que diz respeito aos estudos e pesquisas em Direito e Literatura realizados nos países da América Latina.

Voltemos a Incidente em Antares, de Érico Veríssimo, obra que se insere na estética do realismo mágico e que foi publicada no auge da ditadura militar, como acima exposto. Certamente, sua comicidade e dramaticidade dão-lhe um tom subliminarmente de denúncia das mazelas de uma sociedade. Quem eram os mortos insepultos? E o que eles representavam? O que eles falavam? Todos foram vistos, mas todos falaram por si ou havia intermediários?

Vejamos João Paz! Jovem operário, engajado na luta sindical, preso injustamente e torturado até a morte pela polícia. João Paz foi o último dos mortos insepultos a ser chamado para depor. A testemunha mais importante. No romance, ele visivelmente representa o discurso contra-hegemônico, as vozes marginalizadas, silenciadas e inaudíveis da sociedade brasileira e, em certa medida, da sociedade latino-americana. João Paz não fala. O objetivo, naquele momento, talvez fosse, apenas, dar-lhe visibilidade, colocá-lo à mostra, tirá-lo das sombras do esquecimento. Sua manifestação é física, sua voz é o seu corpo, e seu porta-voz é o Dr. Cícero, também morto insepulto, advogado, articulador e testa de ferro das falcatruas entre os poderosos da cidade. João $\mathrm{Paz}$ não era visto pela sociedade e pelo sistema, precisava ser visto, mas também precisava de alguém para falar por ele, pois não tinha voz. O desafio, naquele momento histórico, era dar visibilidade. Na verdade, o realismo mágico - e Incidente em Antares bem representa isso - pôs luz às mazelas da sociedade latino-americana, tornou visíveis

10 Nesse sentido, buscando ampliar a compreensão e o sentido da polifonia aplicada ao direito, recomenda-se a leitura de Trindade (2017), Trindade e Karam (2018), Espindola e Fantonele (2019).

11 A literatura modernista, de modo geral, é uma literatura da pena privilegiada, ou seja, toda ela feita a partir das vozes e olhares de escritoras e escritores com condições privilegiadas (educação, classe social e econômica etc...). 
os invisibilizados. Mas era preciso mais: era preciso tornar audível, era preciso deixar falar.

A cena do depoimento de João Paz, que encontramos na narrativa de Incidente em Antares, obra publicada em plena ditadura militar, é emblemática para a construção do argumento central que estamos aqui desenvolvendo: há uma especificidade na cultura (e na literatura) latino-americana delineando os contornos dos estudos e pesquisas em Direito e Literatura. O boom latino-americano não foi um movimento polifônico, no seu sentido autêntico. A partir dos anos 80-90, da abertura democrática, é possível identificar - pouco a pouco - a arquitetura de um movimento polifônico: aqueles que estão à margem ganham voz e passam a contar a sua história, mulheres, negros e outros vulneráveis tornam-se sujeitos do discurso ${ }^{12}$. O centro e a periferia são redimensionados. Talvez o estopim desse novo boom não seja inicialmente a literatura, mas a música e a arte em geral, configurando-se como um fenômeno da oralidade ${ }^{13}$. As histórias passam a ser contadas sem intermediários, sem interpostos. Autor, narrador e personagem se integram na mesma pessoa.

A conclusão de Ost (2004) ao afirmar que uma das diferenças entre direito e literatura é que, enquanto o direito produz pessoas, a literatura produz personagens, talvez merecesse aqui alguns reparos: enquanto o direito produz pessoas; a literatura produz personagens que são pessoas a quem o direito dá corpo, mas não dá voz.

É, portanto, a oralidade dos vulnerabilizados que passa a produzir uma nova literatura latino-americana. O desafio não era mais tornar visível, mas tornar audível. A literatura já não pretendia gerar empatia, mas sim alteridade.

Enquanto os primeiros estudos do Direito e Literatura, nos Estados Unidos ${ }^{14} \mathrm{e}$ na Europa ${ }^{15}$, datam do início do século XX (TRINDADE; BERNSTS, 2017), tendo se

12 Observe-se que não se está aqui desconsiderando que literaturas de vozes marginalizadas existissem antes disso. De forma diluída, tivemos vozes representativas como Maria Firmina dos Reis, considerada a primeira romancista negra do Brasil, que escreveu Úrsula, no longínquo ano de 1859, em pleno contexto da escravidão, sendo mulher, negra e filha de escrava. Cite-se, também, Carolina Maria de Jesus, que em 1960 escreveu Quarto de despejo: diário de uma favelada. No entanto, é a partir da redemocratização que se torna possivel identificar um movimento coletivo nesse sentido.

13 Destaque-se, aqui, o papel do rap brasileiro e, em especial, dos Racionais MC's, que se constituíram em 1988 e acabam por ganhar um status de contador de histórias e, portanto, de certo tipo de literatura.

14 Nos Estados Unidos, o ensaio A List of Legal Novels, de John Wigmore, em 1908, é apontado como um marco do movimento teórico do Direito e Literatura (TRINDADE; BERNSTS, 2017).

$15 \mathrm{Na}$ Europa, o marco teórico do Direito e Literatura foi o artigo "Il diritto nella letteratura", de Ferrucio Pergolesi, publicado em 1927, na Itália, e também o ensaio "Das Recht im Bilde", de Hans Fehr, publicado em 1923, na Alemanha (TRINDADE; BERNSTS, 2017). 
desenvolvido significativamente desde então; na América Latina, o Direito e Literatura está em estágio ainda inicial, embora em franca expansão ${ }^{16}$.

Se o realismo mágico exerceu um papel relevante na denúncia da miséria, injustiça e marginalização social, resgatando (e problematizando) construções imaginárias e simbólicas, hoje esse papel talvez esteja sendo desempenhado pela literatura periférica, marcada por denúncias nada fantástica, nada ficcionais, mas marginais ${ }^{17}$.

A literatura marginal ou periférica dessacraliza os cânones na literatura, na mesma proporção em que desvela os contornos e as vozes dos invisibilizados e silenciados, aqueles cuja existência e realidade profana o direito. O Direito, assim como a política, está impregnado de ditames que ordenam a vida e formatam o indivíduo nos moldes do sujeito forjado pelo imaginário jurídico da cultura dominante. Assim como o realismo fantástico contribuiu para profanar o Direito no período da ditadura, também hoje a literatura marginal ou periférica associa-se à necessária profanação revolucionária do Direito, a partir da interação entre Direito e Literatura.

O fato de o movimento Direito e Literatura não ter origem latino-americana não impede que se observe um modo muito particular de suas interseções no contexto latino-americano, a ponto de podermos reconhecer um novo boom latino-americano, cujo catalisador parece ser a literatura dos silenciados, que embora tenha origem nos anos 70, no mesmo contexto do realismo mágico, só no final do século XX aumenta o seu tom de voz e opera num nível de subversão que transgride o próprio cânone da literatura e provoca desordem não só no imaginário jurídico, mas também no imaginário literário.

O boom do direito e literatura pode ser visto como uma alternativa no modo de encarar os desafios que se impõem, nesta segunda década do século XXI, ao novo constitucionalismo latino-americano, operando não apenas como um canal de denúncia das injustiças e de resgate de construções imaginárias e simbólicas, mas problematizando as próprias fontes do imaginário jurídico latino-americano. Por isso, inspirados em Incidente em Antares, talvez possamos perguntar: Quem são os mortos insepultos de hoje? Eles poderão falar por si ou terão intermediários?

16 Possivelmente no Brasil, o marco da produção científica em Direito e Literatura tenha sido a obra A ciência juridica e seus dois maridos, de Luiz Alberto Warat, que se inscrevia no âmbito das narrativas de um realismo mágico, chamando para o diálogo André Breton, Roland Barthes e Mikhail Bakhtin (PEPE, 2016).

17 É interessante considerar que Quarto de despejo, de Carolina de Jesus, foi escrito quase 10 anos antes de Incidente em Antares, de Érico Veríssimo, mas foram necessários 50 anos para que a narrativa da miséria surreal da catadora de lixo recebesse a devida atenção da crítica e da academia. 
No contexto da América Latina, o movimento Direito e Literatura apresenta peculiaridades que não se verificam nos Estados Unidos ou Europa: ele configura-se num novo boom, e esse boom produz impactos no modo de produção do Direito.

\section{5 À GUISA DE CONCLUSÃO}

Todo o argumento deste artigo tem como pressuposto que o Direito, na perspectiva aqui assumida e fundada na metodologia hermenêutico-fenomenológica, não defende apenas posições instituídas, pois possui funções instituintes que lhe são inerentes. Como propõe Ost, o direito envolve a criação imaginária de significações sociais e históricas novas e a desconstrução das significações instituídas que a elas se opõem - tanto é assim que podemos distinguir os discursos hegemônicos dos discursos contra-hegemônicos -; e a literatura não se contenta em atuar na vertente instituinte do imaginário, podendo apoiar-se, também, em formas instituídas, como se evidencia na distinção entre literatura sancionada e literatura proscrita.

De fato, são as intersecções entre o Direito e a Literatura que permitem esse redimensionamento, seja de um, seja de outro. Já a possibilidade de analogia entre o boom latino-americano e o Direito e Literatura sustenta-se tanto pelos rumos peculiares do movimento nos países da América Latina quanto pelas características temáticas e pelas abordagens das pesquisas que vêm sendo desenvolvidas: em ambos os casos, há o evidente compromisso com a reflexão crítica e problematizadora da realidade social e do papel que o direito deve desempenhar nas ainda jovens democracias desses países.

Assim, reconhecer a potência do Direito e Literatura, identificando-o como o novo boom latino-americano, sinaliza para tendências de ajustes que passam pela recuperação (ou revisão) do papel do Direito e, sobretudo, das e dos juristas do século XXI.

A ideia da margem - do marginal - trazida por Warat, no seu clássico A ciência juridica e seus dois maridos, parece ser aqui oportuna e adequada ao boom latinoamericano. $\mathrm{O}$ jurista marginal seria aquele que adota um comportamento transgressor e questionador, condição necessária para reconhecer e dar a conhecer a doxa e a episteme, desvelando a doxa existente na episteme e superando o senso comum acrítico.

$\mathrm{O}$ jurista que se mantem à margem mantém-se em condições de poder fazer um uso permanentemente transgressor do direito, sem ser devorado pelo discurso hegemônico. Os tribunais (assim como a literatura) deveriam ser construídos não como o lugar da identidade, mas como o lugar da multiplicidade, o locus de emergência da singularidade contra a ditadura das certezas culturais. 
Para Warat, a democracia é sempre uma procura de confrontos. O importante nela é assegurar a procura, não sua resolução. Para ele, o conflito é condição de possibilidade do diálogo. Se o conflito não culmina em diálogo, não estamos em um ambiente democrático, e sim num ambiente tirânico, em que o conflito - não possibilitando o diálogo -representa o poder e a força esvaziados do sentido democrático.

\section{REFERÊNCIAS}

BARTHES, Roland. O efeito do real. In: GENETTE, Gérard et al. Literatura e semiologia: pesquisas semiológicas. Tradução Célia Neves Dourado. Petrópolis: Vozes, 1971. p. 35-44.

CANDIDO, Antonio. Vários escritos. 4. ed. Rio de Janeiro: Ouro sobre Azul, 2004.

CARPENTIER, Alejo. Prefácio. In: CARPENTIER, Alejo. O reino deste mundo. Rio de Janeiro: Civilização Brasileira, 1966.

CERVANTES, Aleida Hernandez (coord.). Derecho y literatura: una alianza que subvierte el orden. México (DF): Bonilla Artigas, 2017.

ESPINDOLA, Angela; FANTONELE, Miliane. Decisão judicial, vozes citadas e vozes sobrepostas: é audível a polifonia processual? Revista do Instituto de Hermenêutica Jurídica-RIHJ, Belo Horizonte, v. 17, n. 26, p. 43-54, jul./dez. 2019.

GENETTE, Gérard. Discurso da narrativa. Tradução Fernando Cabral Martins. Lisboa: Veja, [s.d.].

JESUS, Carolina. Quarto de despejo: diário de uma favelada. São Paulo: Ática, 1993.

KARAM, Henriete. Questões teóricas e metodológicas do direito na literatura: um percurso analítico-interpretativo a partir do conto "Suje-se gordo!", de Machado de Assis. Rev. direito GV, v. 13, n. 3, p. 827-865, 2017. Doi: https://doi.org/10.1590/2317-6172201733.

KARAM, Henriete. o direito na contramão da literatura: a criação no paradigma contemporâneo. Revista Eletrônica do Curso de Direito da UFSM, v. 12, n. 3, p. 1022 1043, 2017. Doi: https://doi.org/10.5902/1981369429566.

KARAM, Henriete; ALCÂNTARA, Guilherme Gonçalves. História, Direito e Literatura: uma triangulação em prol do Constitucionalismo. Revista Opinião Jurídica, 
v. 17, n. 24, p. 204-223, jan. 2019. Doi: http://doi.org/10.12662/24476641oj.v17i24.p204-223.2019.

LEAL, Luis. El realismo mágico en la literatura hispanoamericana. Cuadernos hispanoamericanos, México, v. 153, n. 4, p. 230-235, 1967.

MAIA, Gretha Leite. Alumbrar-se: realismo mágico e resistência às ditaduras na América Latina. Anamorphosis - Revista Internacional de Direito e Literatura, Porto Alegre, v. 2, n. 2, p. 371-388, dez. 2016. Doi: http://dx.doi.org/10.21119/anamps.22.371-388.

MARÍ, Enrique Eduardo. Derecho y Literatura. Algo de lo que sí se puede hablar, pero en voz baja. Doxa, n. 21, v. 2, p. 251-287, 1998.

MARTIN, Gerald. Il romanzo di um continente: l'America Latina. In: MORETTI, Franco (a cura di). Il romanzo: storia e geografia. Torino: Einaudi, 2002. v. 3. p. 505529.

OST, François. Contar a lei: as fontes do imaginário jurídico. São Leopoldo: Unisinos, 2004.

PIETRI, U. Letras y hombres de Venezuela. Caracas: Monte Avile Editores, 1995.

$\mathrm{ROH}$, Franz. Postexpressionnisme, réalisme magique: problèmes de la peinture européenne la plus récente. Dijon: Le press du reél, 2013.

RUBIÃO, Murilo. Obras completas. São Paulo: Cia da Letras, 2010.

TRINDADE, André Karam. Processo e polifonia. In: COUTINHO, Jacinto Nelson de Miranda (org.). Direito $\&$ psicanálise: intersecções e interlocuções a partir de "Ensaio sobre a cegueira”, de José Saramago. Rio de Janeiro: Lumen Juris, 2017. p. 35-42.

TRINDADE, André Karam; KARAM, Henriete. Polifonia e verdade nas narrativas processuais. Sequência: Estudos Jurídicos e Políticos, v. 39, n. 80, p. 51-74, 2018.

TRINDADE, André Karam; BERNSTS, Luisa Giuliani. O estudo do direito e literatura no Brasil: surgimento, evolução e expansão. Anamorphosis - Revista Internacional de Direito e Literatura, v. 3, n. 1, p. 225-257, 2017. Doi: http://dx.doi.org/10.21119/anamps.31.225-257.

VEIGA, José J. A hora dos ruminantes. 7. ed. Rio de Janeiro: Civilização Brasileira, 1976.

VERISSIMO, Erico. Incidente em Antares. Rio de Janeiro: Companhia de Bolso, 2006. 
WARAT, L. A. A ciência jurídica e seus dois maridos. 2. ed. Santa Cruz do Sul: EDUNISC, 2000.

WARAT, L. A. Introdução geral ao direito: epistemologia jurídica da modernidade. Porto Alegre: Sérgio Antonio Fabris Editor, 1995.

WARAT, L. A. Introdução geral ao direito: interpretação da lei: temas para uma reformulação. Porto Alegre: Sérgio Antonio Fabris, 1994.

\section{NOTA}

Declaramos que o artigo intitulado "Direito e literatura pelas margens: o novo boom latino-americano e a literatura dos silenciados" - submetido à Revista Opinião Jurídica , é fruto de pesquisa que foi desenvolvida pelas coautoras no âmbito do PPGD da UniFG e que ambas participaram de seu planejamento, execução e revisão, predominando com as seguintes especificidades quanto à redação: Introdução, Seção 3 e Considerações Finais foram elaboradas por Angela Espindola; Seções 1 e 2, por Henriete Karam.

Por ser verdade, firmamos a presente.

Como citar este documento:

KARAM, Henriete; ESPINDOLA, Angela. O direito e literatura pelas margens: o novo boom latino-americano e a literatura dos silenciados. Revista Opinião Jurídica, Fortaleza, v. 18, n, 29, p. 221-242, set./dez. 2020. 